\title{
Causes, Effects And Prevention of Global Financial Crisis In Viewpoint of Islam
}

\section{Gul Ghutai ( $\sim$ gulghutai@sbkwu.edu.pk)}

Sardar Bahadur Khan Women's University https://orcid.org/0000-0003-1270-8375

\section{Sanaullah Ansari}

Shaheed Zulfikar Ali Bhutto Institute of Science and Technology

\section{Research}

Keywords: credit crunch, divine laws, financial crisis, interest rates, Islamic perspective, speculation.

Posted Date: November 19th, 2021

DOI: https://doi.org/10.21203/rs.3.rs-1040703/v1

License: (c) (i) This work is licensed under a Creative Commons Attribution 4.0 International License. Read Full License 


\section{Abstract}

Global financial crisis is not a new phenomenon. The world has witnessed financial crisis since many centuries. The repetition of global financial crisis reveals that global financial setup is not stable thus, prone to frequent financial crisis. However, zero interest rate policy has been launched by developed countries in order to offset the effects of global financial crisis but to date the issue of financial and monetary instability has not been overcome. Interest rate as the main component of financial setup has adversely affected the permanent solution to global financial crisis. The study is undertaken to analyze the effect of interest rate (riba) in propagation of global financial crisis and to analyze the alternate financial mechanism to prevent global financial and economic crisis on permanent basis. However, the qualitative research methodology is pursued to build a conceptual framework by applying inductive paradigm to address the issue of understanding the rationale behind the prohibition of interest based financial paradigm particularly in regard to Islamic perspective. The expected outcome suggests that man-made laws in order to subside divine laws in financial paradigm have given rise to financial, ethical and economic crisis. Global financial crisis is the outcome of easy access to credit, abundance of loans upon interest, speculation, greed as well as corruptive motives to exploit each other.

\section{Introduction And Background}

The term financial crisis is not a new concept instead it has been known since many centuries as the world has witnessed financial crisis repeatedly which includes stock market crash, currency crisis, financial bubble and sovereign default. Since $20^{\text {th }}$ century world has faced so many financial crises including last financial crisis 2007-2009 (Ahmad \& Khan, 2013). However, due to house booming and easy credit policy during 2007-2009 financial crisis occurred while in general due to monitory instability or easy monitory policies financial crisis are repeated periodically (Taylor, 2009). Global financial crisis is the outcome of economic as well as financial policies carried by developed world most prominently United States which has affected the developing countries. Global financial crisis has been transmitted from developed world to developing countries due to financial flow, greater the dependence of developing countries upon developed world with respect to financial flow have been greatly hit by financial crisis. Thus, western global financial crisis resulted in inflation, increased borrowing cost, reduction in per capita income and devaluation of currencies in developing countries (Gurtner, 2010). Before financial crisis of 2008, it was considered that the role of religion in financial system of the world is insignificant and no interconnected relationship exist between financial matters and the religion stated by (Tawney, 2017). The conventional banks operate on the basis of involving Riba, Gharar, exploitations, and Gambling factors. The global financial crisis of 2008 has created distinctive consciousness among end users of banks towards an alternative banking approach to complement conventional banking system which is based upon failed morality considerations as it promotes greed, abuse and corruption. Thus, as an alternative approach Islamic banking got prominence as it is offering very distinctive yet unique features which distinguished it from other banking system (Razak, 2015). During global financial crisis of (2007-2008) the performance of Islamic banking sector was relatively much better in efficiency and performance (Phulpoto, Shah, \& Shaikh, 2012). However, in order to offset the effect of global financial crisis 2007-2009 the central banks of developed world have been switched to unconventional monetary policies. The Central Banks of developed countries since 2008 with the failure of capitalism itself engaged in using lower zero bound policy (Foster, 2019b). Japan has used interest rate at zero percent for the very first time in 1999 to fight deflation and to uplift its economy (Nishad, 2018). United Kingdom since 2009 had been using interest rate near zero percent that is at $0.5 \%$ to 2013 and the central Bank of United States of America is using lower bound interest rate policy by using interest rates of $0.25 \%$ from 2008 until 2013 (Pettinger, 2013) but fluctuating interest does not help them because interest as an exploitation tool was still existent in financial setup. Since financial crisis of 2008 different central banks are using interest rate to zero policy rates but below zero percent interest rates are used by the central banks of European countries like Denmark, Sweden and Switzerland. Since global financial crisis, Swedish Central Bank uses -0.5 interest rates as in 2016 (Eggertsson, Juelsrud, Summers, \& Wold, 2019). However, interest rate above zero, near zero or below zero is prohibited as per Islamic Shariah (Ghutai \& Bahari, 2019). Through the last sermon of Prophet Muhammad (PBUH) during Farewell Pilgrimage 10 A.H (623 AD) it had been clearly conveyed to Muslim Ummah that all forms of Riba becomes invalid and void for you, It is only the principle amount which needs to be paid off (Uddin Ahmed, 2014). If any surplus amount is paid upon

Page 2/8 
loan-based contract then this extra amount upon loan would be considered as riba (Mazhar lqbal, 2006). That is the main reason in regard to developed countries are not achieving desired results to stabilize their economies as the underlying foundation of their economies are based upon secularism and nothing is helpful without solid foundation of divine laws (Ghutai \& Bahari, 2019). Islamic finance helps to reduce inflation by promoting stake in risk of loss and profit through ethically permissible business ventures under Shariah supervision therefore ensures stable economy which forms the basis for development (Sarwer, Ramzan, \& Ahmad, 2013). Islamic banking has not or even very lesser extent affected by financial crisis because it had shown significant growth during financial crisis (Ebrahim, 2011).

\section{Literature Review}

Global financial crisis became drastic during $9^{\text {th }}-10^{\text {th }}$ August, 2007 when the interest rates went so high suddenly (Taylor, 2009). Due to bankruptcy of Lehman Brothers in 2008 the wave of financial crisis propagated and as outcome banks stopped interbank lending and interest rate was rose to $5 \%$ on interbank borrowings. However, regulatory authorities tried to put more liquidity in financial market but eventually economic transactions are declined and thus economies faced severe recession in 2009. In 1997-1998 financial crisis stricken Asian countries (Warwick J. McKibbin, 2010). The repeated financial as well as economic crisis happens due to banking system relying mainly upon instrument of interest and speculations (Ghutai \& Bahari, 2019). However, financial crisis is periodically repeating since the capitalism has been adopted as global financial setup. Due to rise in asset prices has sharply given rise to financial crisis thus, quick rise in asset prices as well as contagion nature of financial crisis are significantly correlated. The Lombard Street has addressed financial crisis of last century and the role of lender of last resort to address the issue. Lender of last resort in a financial crisis must have to lend freely, by applying penalty rate with respect to collateral that is marketable in ordinary course of business while there is no distress (Bagehot, 1873). Thus, financial crisis can be stopped to happen if debt has been granted without interest and reliance upon debt has been restricted by imposing collaterals. Financial crisis has been taking place throughout the centuries and arises due to quick lack of confidence upon the existence of some financial organizations or assets (Charles, 1841); (Kindleberger \& Aliber, 2011). This is because the chain of credit is interlinked with the assumptions regarding the capability of debtors to settle payments therefore, in order to prevent and settle down the spread of financial crisis the existence of lender of last resort is must. Lender of last resort basic role is to provide guarantee of loan within certain confined conditions to stop financial distress to spread or to stop it even to start. Fisher (1945), Simon, (1948), Friedman (1969) and so many others have stated that the exiting financial system of the world based upon interest has been unstable (Gamal, 1998). In 1929 by the Wall Street disintegrate or collapsed, the building of capitalist economy has also been intensely vibrated. The economic shocks let the economists to think about the soundness of structure upon which capitalism is standing. Since 1929 to 1939 due to economic shocks the world has been subjected to exhaust due to the wake of financial problems carried by fragile capitalism opened the doors of seriously ponder upon the economic problems and its solutions. Till $13^{\text {th }}$ century the church rule was having supremacy and taking interest was severely prohibited but allowed rent charged against using land or durable goods by cannon or church law. However, due to gradual decrease in church powers, the secular powers have been increased and interest-based loans has been allowed (Qureshi, 1946). Thus, interest as an exploitative tool with respect to debt is a powerful tool to control civilizations as well as by allowing extracting resources from their economies. With respect to Bagehot rules the IMF as lender of last resort should forward its loans to countries who follows certain rule of requirements especially in context of banking system and foreign banks should be allowed to operate in their countries and loans would be sanctioned on the basis of collateral (C. W. Calomiris, 1998); (C. Calomiris \& Meltzer, 1998). Japan has lowered interest rate for the first time in developed world to zero percent by adopting zero interest rate policy (ZIRP) twenty years back and set an example for aggressive monitory policies of United States and European countries with respect to encounter their own financial crisis years later. Bank of Japan (BOJ) has used Zero Interest Rate policy (ZIRP) in 1999 to avoid deflation by reducing its interest rates to zero percent and since then maintaining unconventional monetary policy in one way or the other way. Since then US, Europe and Japan is using the policy in more or less extent like Japan and European countries are still using near zero or below zero percent interest rate however United States is $-2.5 \%$ but still the ultimate outcome of zero interest rate (ZIR) policy implications by three major economies of the 
world like United States of America (USA), Japan and Europe has not been realized in its real sense because all the three have not exited from it. Though the concept of ZIRP adopted by BOJ was controversial at that time but still its potential impact and outcome has been poorly understood even by BOJ's officials implementing it (Scaggs, 2019). The experience of Japan for last 20 years of using zero lower bound policy in one way or the other way shows the extent and power of central bank to take steps by their own by underscoring the importance of broader economic reforms as well as fiscal policy in connection with monetary program as stated (Miller \& Fujioka 2019). Applying near zero bound or below zero bound upon interest the presence of interest as an exploitative tool cannot be overcome (Ghutai \& Bahari, 2019). United Kingdom has been using zero lower bound rates by reducing interest rate to $0.5 \%$ and stayed at same lower bound percentage since March 2009 to 2013. Likewise, in USA, the Federal Reserve Bank adopted zero lower bound monetary policy by reducing interest rates in between 0\% to 0.25\% since December 2008 till 2013 stated by (Pettinger, 2013). Whether interest is near to zero or just below zero, it will still be interest unless interest has been completely omitted upon debt such as zero interest upon loan (Ghutai \& Bahari, 2019). The world has witnessed crisis which is frequent, contagion in nature and virulent and spreads throughout the world financial markets therefore, it is inevitable to restructure or redesign to strengthen international financial system to reduce the frequency and intensity of financial crisis as well as to strengthen global capital markets and domestic capital markets as the financial crisis that raised in 1994 in Mexico then in 1997 and 1998 of east Asia spread to Russia, Europe and Latin America, (Fischer, 1999). Interest rate upon long term Government bonds has been at its lowest value since last 150 years with respect to developed economies. The global secular forces are the sole authority in creating low interest rate situation where real interest rate lie at $2 \%$ for more than 40 years. This situation has been arisen due to the motives of investors for safety as well as liquidity and response towards low growth in global economy. The trend in real interest rate has been started fallen after 1980's and even in 2016 it had been having been $0.5 \%$. The secular trend in decreasing rate of real interest is highly reflecting a global incidence. Such as, real interest rate has been reduced in advanced economies especially in UK, Germany, France, Italy, Japan, Canada and United States of America. Lower interest rates in developed countries is purely a secular situation and has been brought up by global forces who are having specific stakes and connection within certain countries national policies as well as internal developments. Thus, whatever the forces in future will increase real interest rates will also be global (Negro, Giannone, Giannoni, \& Tambalotti, 2019). Western developed world has adopted lower interest or near zero interest rate helps workers or labor market. The Federal Reserve Banks decision to keep zero interest rate policy in place may not be good for investors of Wall Street but it is good news for labor market or workers. The economy where millions of workers could not find job while they want to do job, and millions of workers did not get permanent jobs, where wages or salaries are stagnant provides most sound justification towards keeping interest rate lower. Higher interest rates will result in fewer jobs as well as lower wages (Baker, 2015). However, man-made laws became invalid if it contradicts divine laws (Blackstone, 2014). The history of Islamic finance is as old as divine religions are to date (Uddin, 2015). All divine books have guided human beings to carryout economic activities without interest so that wellbeing of humans can be assured. In experimentation with interest rates by developed countries to stabilize global financial setup would not result in rescuing the existing fragile financial setup because without divine guidance financial crisis cannot be[1] overcome. In order to reap the fruit of complete interest free economic paradigm countries needs to abolish interest from their economies to realize divine barakah. Without inculcating Islamic values of sharing and redistribution of wealth as practiced in Islamic societies back in 1400 AD, the existing Muslim regimes cannot be able to solve its economic, financial and social problems (Moisseron, Moschetto, \& Teulon, 2015).

\section{Methodology}

The study upon causes, effect and prevention of global financial crisis in view point of Islam is undertaken by pursuing qualitative research methodology. The conceptual framework is followed inductively to address the issue of global financial crisis which arises mainly due to interest rates and speculative measures carried forth under conventional financial setup. Therefore, in all divine religions particularly Islam, interest is prohibited as it results in exploitation of fellow human beings. Moreover, promoting riba based financial, monetary and economic setup in personal pursuits against divine guidance will always result in fragile, unstable economic and financial regimes globally. 


\section{Discussion}

Financial crisis of 2008-2009 has led the wave of Privatization to keep Governments solvents. Through financialization process financial markets, organizations and aristocrats holds greater control upon economic policies and respective outcomes. The risk of having another economic and financial crisis is higher. The global debt has raised very high and hit US\$ 164 Trillion in 2016, which is parallel to 225 percent of global Gross Domestic Product. It is expected that the next financial crisis may hit developing countries and with much more intensity than developed world because private capital has been moved towards developing world to earn higher returns due to lower interest rates and quantitative easing policies of developed world (Schwab, 2017). After global financial crisis of 2007 the global economy has been in the state of recovering out of financial crisis but at the same time loans of the world has been raised to trillions of dollars. Global debt to GDP ratio has been risen 400 percent as the volume of world-wide debt has been risen which could give rise to another financial crisis of a much severe nature (Seyf, 2018). As in today's world, economic problem is regards as the sole problem amongst residents of this world. Self-interest, maximization of profit as well as satisfying nasty needs is the sole purpose of today's secular world (UI Hassan, 2010). Thus, Economic systems based upon interest has given rise to other economic problems and needs solid foundations of religion to address economic problems in certain regimes. Capitalism is failed for being a social system. Therefore, the world is looking for new financial system to be adopted (Foster, 2019a). It has been discussed so many times that zero lower bound rate could be eliminated with the elimination of paper currency from the economies and give rise to electronic money (Agarwal, 2015). Thus, it shows that zero or near to zero percent interest is not a new phenomenon adopted since very long ago to offset financial crisis but could not have stopped these crises respectively. Whether interest rate is almost zero or below zero it is still interest based upon exploitation and injustice with respect to divine decree against humans. World by itself has witnessed that lower interest or near zero interest since centuries could not have stopped world from economic as well as financial shocks apart from social crisis it has caused since centuries amongst residents of the world. In today's world, human has been acting as an economic animal and has become slave of one-eyed intellectuals in different professions viewing every problem with their microscopic approach. There is a need to devise a strategy to solve moral and ethical problems of the world (Maududi, 1970). All economic activities carried by risk sharing factors ensures the wellbeing of all market participants particularly and society generally. Without risk sharing factor the vulnerability of conventional financial institutions relying upon debt financing is reinvested by the repetition of financial crisis (Maghrebi \& Mirakhor, 2015). The interest, riba or usury is prohibited in Islam because lending upon interest does not produce any new wealth in the economy (Kahf, 2013). However, there is firm zero percent interest or without interest in Islam but if any rate is set above zero rate then it will give rise to usurious rate of interest (Qureshi, 1974). The involvement of economic participants through conventional banking setup on the basis of risk sharing principles, without any interest and gharar is possible (Ghutai \& Bahari, 2019). Because, Islamic economics philosophy lies upon without riba and is based upon the distribution of wealth amid market participants as a reward for taking risk hence, discourages wealth in few hands through interest-based earnings and wealth hoardings (Imran, 2002). Islamic banking refers to without interest and not zero return (Sharawy, 2000). Return upon investment is the reward for participation of sharing risk among market participants for carrying out economic activities. The philosophical underpinning of interest free phenomenon kept the logic of condemning injustice, exploitation and oppression against human beings flourished by capitalism (Ghutai \& Bahari, 2019). Riba is condemned because it increases gap in poverty as $60 \%$ of resources in the world are accumulated and used by $20 \%$ of world's rich people (Arif, Hussaini, \& Azzem, 2012). The reason for survival of majority of Islamic banking segment around the world during global financial crisis lies in the fact that Islamic banks avoid interest-based dealings, gambling factors, short selling and its financing is based upon equity and debt-based instruments. It encourages involvement of all market participants through profit and loss sharing basis, which opposes conventional banks debt financing as Islamic banks financial products are backed by assets and thus increased stability during market crisis is maintained (Pappas, Ongena, Izzeldin, \& Fuertes, 2017). The Islamic tasawor of zero interest rate financing is the complete abolishment of interest or riba against bank loans. Because the Islamic tasawor of interest free financing is based upon divine law derived from Quran and Sunnah of Prophet Muhammad PBUH and it is based upon the ontology of Akhirah concept which is the life after this world.

\section{Conclusion}

Page 5/8 
The existing world's financial and economic setup is filled with chaos and uncertainty which is basically due to interest and speculative practices. By segregating religion from financial and economic affairs of the world has widened the doors of miseries for residents of the world. The only true model of economy lies in incorporating divine guidelines towards establishing global financial setups without any crisis. As financial crisis is the outcome of easy access to credit, abundance of loans, speculation, greed as well as corruptive motives to exploit each other. The economic system of the globe is unstable due to human deeds targeting quick returns out of their investments. Thus, as an outcome financial crisis is repeated with much intensity whether by the burst of housing bubble, credit crunch, asset bubble, economic meltdown etc. as suffered by United States of America and Euro zone.

\section{Declarations}

Competing Interests: Not applicable.

Funding: Self / Employer

Authors' contribution:

This paper addresses the issue of understanding the rationale behind the prohibition of interest based financial paradigm particularly regarding Islamic perspective so that financial and economic crisis shall be safeguarded.

Acknowledgments: Not applicable.

Availability of data and materials: Conceptual Paper

Authors Information:

\section{Gul Ghutai (Lecturer)}

Sardar Bahadur Khan Women University (SBKWU),

Brewery Road, Quetta 87300, Pakistan.

gul.ghutai@student.usm.my

\section{Sanaullah Ansari (Asst: Professor)}

Shaheed Zulfikar Ali Bhutto Institute of Science and Technology (SZABIST),

Plot \# 67, Street \# 9, Sector H-8/4, Islamabad 44000, Pakistan.

sanaullahansari@hotmail.com

\section{References}

1. Agarwal R (2015) Breaking through the zero lower bound. International Monetary Fund

2. Ahmad N, Khan JI (2013) Global Financial Crisis: Is There a Remedy. Available at SSRN 2739307

3. Arif M, Hussaini A, Azzem M (2012) Riba Free Economy Model. International Journal of Humanities and Social Sciences 2(6):141

4. Bagehot W (1873) Lombard Street: A description of the money market. HS King, London

5. Baker D (2015) Zero interest rate policy may be bad for Wall Street but it's good for workers Retrieved from https://www.theguardian.com/business/2015/sep/19/zero-interest-rate-policy-wall-street-workers 
6. Blackstone W (2014) Commentaries on the Laws of England. Retrieved from https://ebooks.adelaide.edu.au/b/blackstone/william/comment/complete

7. Calomiris C, Meltzer AH (1998) Reforming the IMF. Unpublished.

8. Calomiris CW (1998) Blueprints for a new global financial architecture. International Financial Markets: The Challenge of Globalization

9. Charles M (1841) Extraordinary popular delusions and the madness of crowds. Radford, VA: Wilder

10. Ebrahim MS (2011) Islamic Banking in Sudan. Available at SSRN 1926895

11. Eggertsson GB, Juelsrud RE, Summers LH, Wold EG (2019) Negative nominal interest rates and the bank lending channel (0898-2937). Retrieved from

12. Fischer $S$ (1999) On the need for an international lender of last resort. Journal of economic perspectives 13(4):85-104

13. Foster JB (2019a) Capitalism Has Failed-What Next? MONTHLY REVIEW-AN INDEPENDENT SOCIALIST MAGAZINE 70(9):1-24

14. Foster JB (2019b) Capitalism Has Failed-What Next? Retrieved from https://monthlyreview.org/2019/02/01/capitalism-has-failed-what-next/

15. Gamal ME- (1998) The survival of Islamic banking: A micro-evolutionary perspective.Islamic Economic Studies, 5(1)

16. Ghutai G, Bahari Z (2019) ZERO INTEREST RATE: FROM THE PERSPECTIVE OF ISLAMIC TASAWUR AND EPISTEMOLOGY. International Journal of Accounting 4(22):1-9

17. Gurtner B (2010) The Financial and Economic Crisis and Developing Countries. The Financial and Economic Crisis and Developing Countries 189-213. doi:DOI: https://doi.org/10.4000/poldev.144

18. Imran MAU (2002) Meezan Bank's Guide to. Islamic Banking. Darul-Ishaat Karachi, Pakistan

19. Kahf DM (2013) Fatwas of Muslim Minorities Series 1; Onlslam.net Retrieved from https://www.academia.edu/5970430/Islamic_Finance_Question_and_Answer_Fatwas_of_Muslim_Minorities_Series_1_... Onislam.net

20. Kindleberger CP, Aliber RZ (2011) Manias, panics and crashes: a history of financial crises. Palgrave Macmillan

21. Maghrebi N, Mirakhor A (2015) Risk sharing and shared prosperity in Islamic finance. Islamic Economic Studies 130(2223):1-31

22. Maududi S (1970) Economic Problem of man and its Islamic Solution. Islamic Publications Ltd., Lechore, Dacca, Karachi

23. Mazhar lqbal M (2006) A broader definition of Riba. Pakistan Institute of Development Economics working paper

24. Miller B, Fujioka T (2019) How Japan (Eventually) Changed the World With Zero Rates. Retrieved from https://www.bloomberg.com/news/articles/2019-02-05/land-of-cheap-money-marks-20-years-since-zero-interest-rates

25. Moisseron J-Y, Moschetto B-L, Teulon F (2015) Islamic finance: a review of the literature. International Business \& Economics Research Journal (IBER) 14(5):745-762

26. Negro MD, Giannone D, Giannoni MP, Tambalotti A (2019) Global trends in interest rates. J Int Econ 118:248-262

27. Nishad PN (2018)Effectiveness of Japan's Zero and Negative Interest rate Policy

28. Pappas V, Ongena S, Izzeldin M, Fuertes A-M (2017) A survival analysis of Islamic and conventional banks. J Financial Serv Res 51(2):221-256

29. Pettinger T (2013) Zero lower bound rate (ZLB). Retrieved from https://www.economicshelp.org/blog/7603/economics/zero-lower-bound-rate-zlb/

30. Phulpoto LA, Shah AB, Shaikh FM (2012) Global Financial Crises and its Impact on Banking Sector in Pakistan. Journal of Asian Business Strategy 2(6):142

31. Qureshi Al (1946) Islam and the theory of interest. Shaikh M: Ashraf

32. Qureshi Al (1974) Islam and the Theory of Interest: With a New Chapter on Interest Free Banking. Sh. Muhammad Ashraf 
33. Razak AHA (2015) The Fundamentals Of Islamic Banking and Finance: A Prologue. European Journal of Islamic Finance(2).

34. Sarwer MS, Ramzan M, Ahmad W (2013) Does islamic banking system contributes to economy development.Global Journal of Management and Business Research

35. Scaggs A (2019) After 20 Years, Has Japan Redefined Monetary Policy Success? Retrieved from https://www.barrons.com/articles/japan-dropped-interest-rates-to-zero-20-years-ago-theyre-still-there-51549994899

36. Schwab (2017) The Global Competitiveness Report $2017 \square 2018$

37. Seyf A (2018) Hoarding, Low investment and the Great Recession, A Vicious Circle. Retrieved from https://www.landecon.cam.ac.uk/research/real-estate-and-urban-analysis/centres/ccepp/copy_of_ccepppublications/wp03-18

38. Sharawy HM (2000) Understanding the Islamic prohibition of interest: A guide to aid economic cooperation between the Islamic and Western worlds. Ga J Int'I \& Comp L 29:153

39. Tawney RH (2017) Religion and the Rise of Capitalism. Routledge

40. Taylor JB (2009) THE FINANCIAL CRISIS AND THE POLICY RESPONSES.

41. AN EMPIRICAL ANALYSIS OF WHAT WENT WRONG. (No. W14631)

42. Uddin Ahmed M (2014) Riba, Bank Interest, and Islamic Banking: A Summarised Response to Fundamental Questions.New Horizon(191),23-28

43. Uddin MA (2015) Principles of Islamic Finance. Prohibition of Riba, Gharar and Maysir

44. Ul Hassan M (2010) Islamic Approach of Economics: Some Discourses on Khurshid Ahmad's Vision of Socio-Economic Order, Self-Reliance and Economic Development

45. Warwick J, McKibbin AS (2010) The Global Financial Crisis: Causes andConsequences. Asian Economic Papers 9(1):54-86. https://direct.mit.edu/asep/article/9/1/54/17748 